\title{
Racial Geography, Economic Growth and Natural Disaster Resilience ${ }^{1}$
}

\author{
Huiping $\mathrm{Li}^{*}$ Steven J. Fernandez ${ }^{\vee}$ Auroop Ganguly ${ }^{+}$
}

\section{Introduction}

Recent development of National Response Plans and National Incident Management Plans has emphasized the need for interoperability of plans, systems, technology, and command structures. However, much less emphasis has been placed on equally important elements such as the at-risk populations' response to those plans, systems, and directions. The community-wide consequences of Hurricane Katrina demonstrated that the protection of communities should no longer be considered only a function of public organizations. Private organizations, nonprofit organizations and individual households have significant roles to play in these plans (Comfort 2006, Salamon 2002).

This study is a first attempt to characterize the effect on the resilience (recovery) of metropolitan areas by the presence (or absence) of separate small communities within a larger jurisdiction. These communities can be based on many different social cleavages (ethnic, racial, economic, social, geographic, linguistic, etc.).

Several researchers have suggested that emergency planners and urban planners have fewer coordination issues and more uniform responses to directions and policies when those plans and policies are supported by leaders with wide acceptance within the small communities and neighborhoods (Comfort 2006). There has also been much discussion about the relationship between integrating communities into a common emergency preparedness structure and a larger jurisdiction's ability to restore essential services in the aftermath of a natural disaster. Recovery is slowed when plans ignore or deemphasize the role of neighborhood leadership.

\footnotetext{
${ }^{1}$ THE ROLE OF SOCIAL SCIENCE RESEARCH IN DISASTER PREPAREDNESS AND RESPONSE, HEARING BEFORE THE SUBCOMMITTEE ON RESEARCH, COMMITTEE ON SCIENCE, HOUSE OF REPRESENTATIVES, ONE HUNDRED NINTH CONGRESS FIRST SESSION, NOVEMBER 10, 2005, Serial No. 109-32, Available via the World Wide Web: http://www.house.gov/science

*University of North Carolina at Charlotte, hli9@uncc.edu

• Oak Ridge National Laboratory, fernandezsj@ornl.gov

+ Oak Ridge National Laboratory, gangulyar@ornl.gov
} 
In this study we will examine the hypothesis that those urban areas composed of conglomerations of smaller communities suffer slower recovery from natural disasters than more integrated communities where response is more uniform. These issues are important as part of an overall effort to define, characterize, and build America’s resilience to natural disasters.

\section{Natural Disaster Resilience}

In this paper resilience is defined as the capacity of a system, community or society potentially exposed to hazards to adapt, by resisting or changing, in order to reach and maintain an acceptable level of functioning and structure. Resilience is dependent upon the degree to which the social system is capable of organizing itself to increase its capability for learning from past disasters for better future protection and to improve risk reduction measures (National Science and Technology Council 2005). This paper emphasizes on the ability of a community to restore essential socioeconomic functions after a community-wide disruption. Thus, resilience is proxied by the recovery of socioeconomic activities and the workforce. By examining the relationship between racial geography, economic growth and restoration of essential socioeconomic activities, we hope to provide insights to improve future plans and actions by policymakers seeking to develop comprehensive plans to build resilient communities.

As a first step, a resilience index was created following the Political, Security, Economic, Social, Infrastructure, and Informational framework, and using the socioeconomic data from Katrina-affected areas in Mississippi and Louisiana. This framework is a convenient construct to categorize the multi-sector variables that may influence a community's resilience. A resilience index measuring the recovery capability of the entire community after the disruption from a disaster must indicate the recovery (or restoration) of essential functions of political, security, economic, social, infrastructure and information dimensions in a community. A correlation analysis was then conducted to investigate the relationship between racial geography, economic growth and natural disaster resilience.

We chose Biloxi-Gulfport-Pascagoula, MS Metropolitan Area (MA) and New Orleans Metropolitan Area (MA) as our selected use cases. The study area included nine counties and parishes that are located in the Katrina impact area. The nine counties and parishes were Hancock County, Harrison County, and Jackson County in Mississippi, and Jefferson Parish, Orleans Parish, Plaquemines 
Parish, St. Bernard Parish, St. Charles Parish, St. Tammany Parish in Louisiana. ${ }^{2}$ The three counties compose the Biloxi-Gulfport-Pascagoula, MS MA and the six parishes are components of New Orleans MA.

Data were compiled from Bureau of Economic Analysis, U.S. Census Bureau, U.S. Census of Government, County and City Data Book, U.S. Department of Housing and Urban Development, U.S. Department of Labor and U.S. Bureau of Labor Statistics, Mississippi State Tax Commission, Louisiana Department of Revenue, Mississippi Department of Education, Louisiana Department of Education and the Congressional Research Service (CRS). Appendix 1 describes the data and the associated sources.

We limited data collection to information about population return, employment, tax and building permit restoration and school re-openings for social and economic dimensions. Population, housing, school, employment and sales tax are significant social and economic indicators of a community's functions. In this project, population return was measured by the percentage of the population in July 2006 of that in July 2005. Employment was defined as the percentage of the employment rate in August 2006 compared with the employment rate before Katrina. Sales tax was assumed to be the indicator for economic activities. Because of data availability, we used natural resources severance tax as the alternative measurement. Severance tax is levied on production of natural resources taken from land or water bottoms within the territorial boundaries of the state (Louisiana Department of Revenue). We used it to roughly indicate the production activities. Ratio of the estimated natural resources severance tax in 2006 to the actual tax in 2006 was used as the tax restoration measurement. The building permit indicator was calculated as the percentage of the average building permit from October 2005 to February 2006 compared with the average from March 2005 to August 2005. School re-openings were measured by the ratio of opened schools by Dec. 2006 to the pre-Katrina number. Values for these five measurements are listed in Table 1.

\footnotetext{
${ }^{2}$ We eliminated St. James Parish and St. John the Baptist Parish of New Orleans Metropolitan Area because of data availability.
} 
Table 1: Social and Economic Indicators of each community

\begin{tabular}{|c|c|c|c|c|c|}
\hline County & $\begin{array}{l}\text { Population } \\
\text { return }\end{array}$ & Employment & Severance tax & $\begin{array}{l}\text { Re-opened } \\
\text { school }\end{array}$ & Building permit \\
\hline Hancock & 0.75 & 0.859 & 0.619 & 0.92 & 0.769 \\
\hline Harrison & 0.83 & 0.903 & 1.948 & 0.98 & 0.467 \\
\hline Jackson & 0.94 & 0.98 & 0.666 & 1 & 0.8 \\
\hline Jefferson & 0.91 & 0.908 & 0.804 & 0.9 & 0.325 \\
\hline Orleans & 0.36 & 0.633 & 0.012 & 0.43 & 0.071 \\
\hline Plaquemines & 0.71 & 0.947 & 0.673 & 0.9 & 0.114 \\
\hline St. Bernard & 0.05 & 0.469 & 0.338 & 0.2 & 0 \\
\hline St. Charles & 1.04 & 1 & 0.938 & 1 & 0.978 \\
\hline $\begin{array}{l}\text { St. } \\
\text { Tammany }\end{array}$ & 1.01 & 1.032 & 2.298 & 1 & 0.470 \\
\hline
\end{tabular}

Our analysis shows these five measurements are highly correlated as indicated in Table 2 below. Based on these correlations, we combined these five measurements in three ways by:

1) simple summation,

2) sum of the standardized values, and

3) principle component analysis

to create a socioeconomic resilience index.

For example, using method (1):

The socioeconomic resilience index $=$ population return +employment + severance tax + re-opened school + building permit. Thus the resilience index of Hancock County is $4.458(.75+.859+.619+.92+.769)$.

By summing the standardized values of each indicator we can get the resilience index value for method (2). Again, the resilience index of Hancock County is .931 $(.05+0-.41+.362+.930)^{3}$.

The resilience index of Hancock County through a principle component analysis is $.428(.497 *$ population return $+.490 *$ employment $+.340 *$ severance tax $+.494 *$ re-opened school $+.392 *$ building permit $)^{4}$.

\footnotetext{
${ }^{3}$ They are the standardized values of population return, employment, severance tax, re-opened school and building permit. We use the standardized values to avoid the possibility that variance of one variable may dominate the variance of the resilience index obtained from simply summation of the raw values.

${ }^{4}$ The coefficients of each variable are from the principle component analysis. We use the three different methods to identify the weights to assign for each variable.
} 
The correlation coefficients among these three values were greater than 0.91 (see table 2 as below). The high mutual correlations suggest these three approaches to calculating a resilience index may proxy the same restoration process with similar levels of skill. To explore the validity of the socioeconomic resilience index, we compared these three indices with the social vulnerability index created by Cutter (2003). The correlation coefficients are all approximately -0.71 . Vulnerability and resilience (when defined as recovery capability) are two reverse attributes of a community. The high and negative correlation coefficient provides some confidence that the socioeconomic resilience indices are reasonable measures for the recovery capability of a community.

\section{Table 2: Correlations of the Resilience Components.}

\begin{tabular}{|c|c|c|c|c|c|c|c|}
\hline \multirow{2}{*}{\multicolumn{8}{|c|}{ (1)population }} \\
\hline & & & & & & & \\
\hline (2)employment & 0.974 & 1 & & & & & \\
\hline (3)severance tax & 0.595 & 0.599 & 1 & & & & \\
\hline $\begin{array}{l}\text { (4)re-opened } \\
\text { school }\end{array}$ & 0.967 & 0.976 & 0.596 & 1 & & & \\
\hline (5)building permit & 0.743 & 0.662 & 0.278 & 0.717 & 1 & & \\
\hline (6) $\mathrm{R}$ & 0.859 & 0.850 & 0.918 & 0.850 & 0.575 & 1 & \\
\hline (7)Rz & 0.976 & 0.961 & 0.700 & 0.971 & 0.776 & 0.924 & 1 \\
\hline (8)pca_R & 0.983 & 0.970 & 0.673 & 0.978 & 0.775 & 0.910 & 0.999 \\
\hline
\end{tabular}

Note: $\mathrm{R}$ is the simple summation of the five variables. $\mathrm{Rz}$ is the summation of standardized values. Pca_R is the result from a principle component analysis on the standardized values.

\section{Racial Geography and Natural Disaster Resilience}

We defined racial geography as the residential distribution of the population by self-identified race. The dissimilarity index, the most popular racial segregation index, was chosen as the indicator for this study. Its formula is: $R D I=\frac{1}{2} \sum_{i=1}^{N}\left|\frac{b_{i}}{B}-\frac{w_{i}}{W}\right|$

where

$b_{i}=$ the black population of the $i^{\text {th }}$ census tract

$\mathrm{B}=$ the total black population of the county (parish)

$\mathrm{w}_{\mathrm{i}}=$ the white population of the $\mathrm{i}^{\text {th }}$ census tract

$\mathrm{W}=$ the total white population of the county (parish) 
The dissimilarity index was calculated based on the 2000 census tract data. Table 3 shows the results of the correlation analysis among racial geography, economic growth, poverty rate, local government number, local government revenue from personal income tax, and the resilience indices described earlier (See appendix two for the values of each county/parish).

\section{Table 3: Results from correlation analysis}

$\begin{array}{lllllllll}\text { (1)racial geography } & (1) & (2) & \text { (3) } & \text { (4) } & \text { (5) } & \text { (6) } & \text { (7) } & \text { (8) } \\ \text { (2)income growth } & 1 & & & & & & & \\ \begin{array}{l}\text { (3)poverty } \\ \text { (4)general-purpose }\end{array} & 0.502 & 1 & & & & & & \\ \text { government } & 0.099 & 0.748 & 1 & & & & & \\ \begin{array}{l}\text { (5)general government } \\ \text { revenue per capita }\end{array} & -0.351 & -0.677 & -0.277 & 1 & & & & \\ \text { (6)R } & -0.640 & -0.306 & 0.042 & -0.123 & 1 & & & \\ \text { (7)Rz } & -0.600 & -0.817 & -0.643 & 0.733 & 0.442 & 1 & & \\ \text { (8)pca_R } & -0.668 & -0.828 & -0.578 & 0.587 & 0.576 & 0.924 & 1 & \\ & -0.666 & -0.811 & -0.560 & 0.573 & 0.592 & 0.910 & 0.999 & 1\end{array}$

Note: Income growth is measured by the average growth rate of personal income per capital from 2001 to 2004. General-purpose government is the total number of general purpose government of each county (parish) in 2002. General government revenue per capita is the total general government revenue per capita of each county (parish) in 2002.

According to Drier (2006) Katrina did not damage all neighborhoods and communities equally. Most of the population of the flooded neighborhoods was minority and the storm wiped out most of the high-poverty census tracts (Brookings 2005). The high negative correlation coefficients between racial dissimilarity and the resilience indices from our case study (showed in Table 3 and particularly by Graph 1), however, suggests that segregated residential structure is associated with the community recovery process from the disruption. This result supports our hypothesis in the problem statement. 


\section{Graph 1: Racial geography negatively correlates with socioeconomic resilience of the communities.}

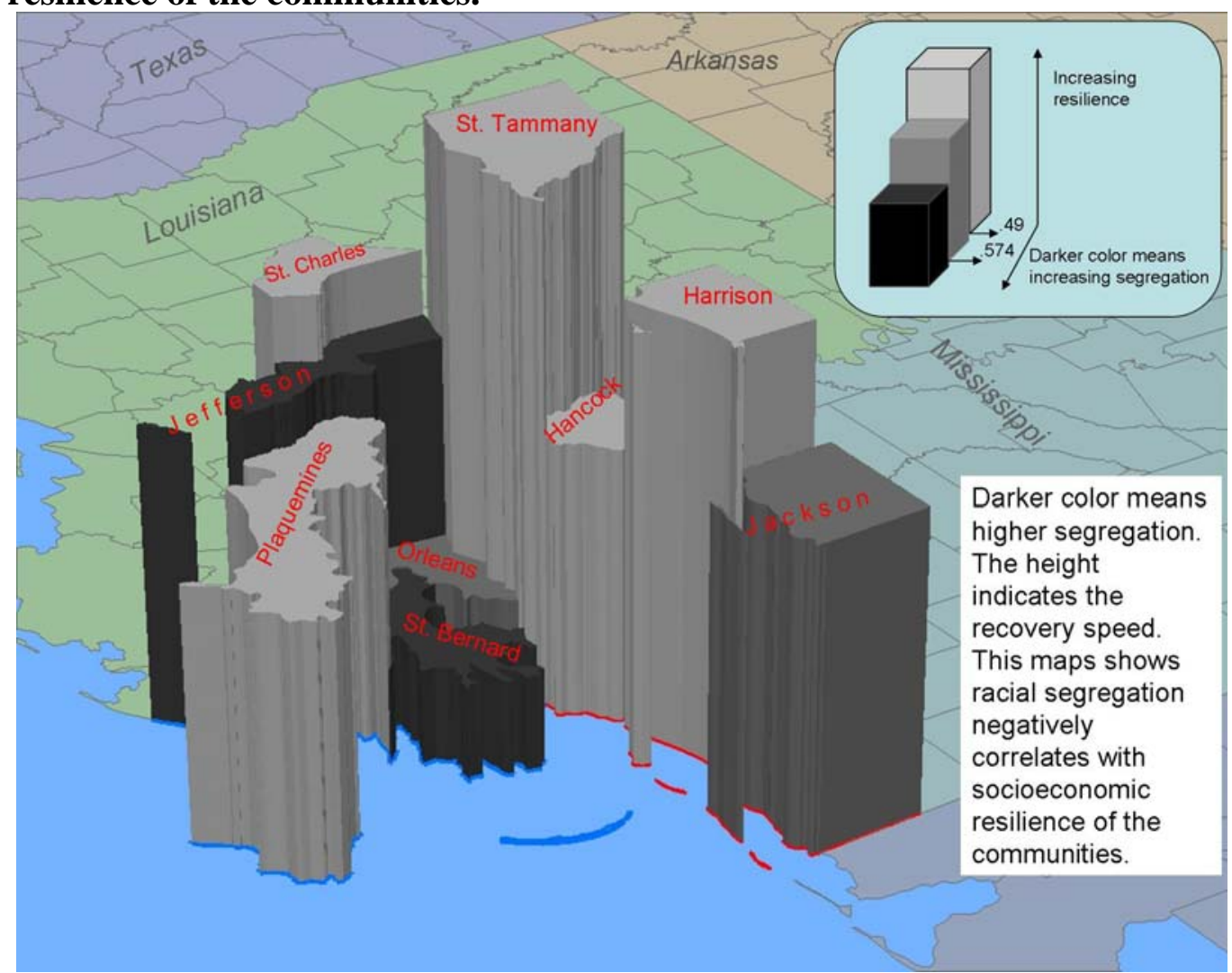

Previous research argues that a resilient community requires active civic engagement that includes all sectors of its population in a socio-technical framework that enables individuals and organizational learning (Comfort 2005). Thus, the key to creating a resilient community is to integrate different groups within the community with different degrees of exposure to risk, different levels of access to resources for mitigating risk, and different rates of change and adaptation to a threatening situation, to achieve a coherent strategy. Developing such a capacity is a major task for community and emergency planners. Although mechanisms are unclear, the negative correlation indicates that the segregated residential distribution of race may impede the grassroots' or localities' participation in coordinating recovery efforts and in building an actively coherent resilience strategy as the literature suggested. 


\section{Economic Growth and Natural Disaster Resilience}

Economic growth was measured by the personal income per capita growth rate from 2000 to 2004 and collected from the Bureau of Economic Analysis. We selected the number of local government and the revenue of the county government as the measurements indicating the restoration of governmental capability to help the community recover. Poverty rate was also calculated based on 2000 census data.

The negative relationship between racial geography and natural disaster resilience suggests that perhaps the more segregated central-city areas recover slower than suburbs. Yet Graph 2 shows central cities actually recovered sooner from Katrina than suburbs in our case study. In Biloxi-Gulfport-Pascagoula MA, essential socioeconomic functions restored earlier in the two central counties (Harrison and Jackson) than the suburban county (Hancock). In the New Orleans MA, the suburban parish, Plaquemines, ranks behind the three central parishes and only ahead of Orleans and St. Bernard. In addition, Table 3 shows a strong negative correlation between economic growth and resilience indices. 


\section{Graph 2: Resilience of Central and Suburban Areas in each MSA}

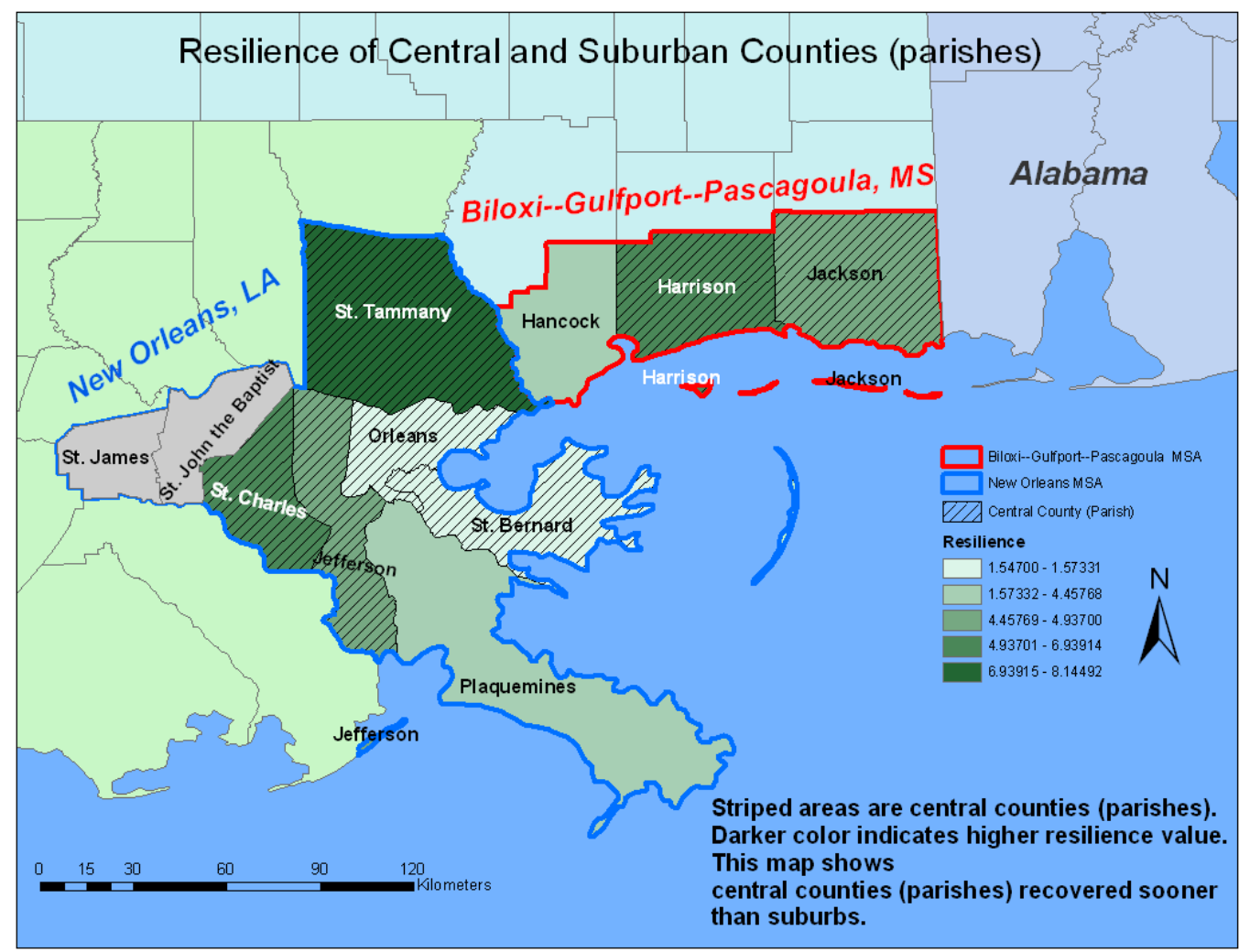

Poverty rate negatively correlates with resilience indices. The number of local government and the general revenue of government per capita are positively correlated with the resilience indices. Although there are many confounding factors, the correlation might suggest that speed and comprehensiveness of government efforts are important for the community restoration procedure after a disaster. Because the economy is based on low-wage jobs and the poverty rate is high in this area, the local governments are constrained financially to enact effective policies to drive back the communities from the disruption. Therefore, the negative correlation between economic growth and resilience indices might result from a community's economic resources (market power) independent of federal assistance. We chose the top three major industries in each county (or parish) as the proxy for market power of each jurisdiction. These three industries are the most important sources of personal income of each county (or parish). Data is from Bureau of Economic Analysis. We contrasted the top three major industries in each county with the resilience index to examine the role of the industrial structure of the local economy in community resilience. Table 4 shows the industrial mix and the resilience index of each county (or parish). 
Table 4: Major industries of each county (or parish)

\begin{tabular}{|c|c|c|}
\hline counties & Industries & $\mathbf{R}$ \\
\hline & $\begin{array}{l}\text { Government and government enterprises } \\
\text { Accommodation and food services }\end{array}$ & \\
\hline Harrison (1) & Health care and social assistance & 6.939 \\
\hline Jackson(1) & $\begin{array}{l}\text { Manufacturing } \\
\text { Government and government enterprises } \\
\text { Health care and social assistance }\end{array}$ & 4.937 \\
\hline Hancock(2) & $\begin{array}{l}\text { Government and government enterprises } \\
\text { Professional and technical services } \\
\text { Manufacturing (nondurable) }\end{array}$ & 4.458 \\
\hline Louisiana & & \\
\hline St. Tammany (1) & $\begin{array}{l}\text { Government and government enterprises } \\
\text { Health care and social assistance } \\
\text { Retail trade }\end{array}$ & 8.145 \\
\hline St. Charles(1) & $\begin{array}{l}\text { Manufacturing } \\
\text { Government and government enterprises } \\
\text { Construction }\end{array}$ & 5.917 \\
\hline Jefferson (1) & $\begin{array}{l}\text { Government and government enterprises } \\
\text { Health care and social assistance } \\
\text { Retail trade }\end{array}$ & 4.854 \\
\hline Plaquemines(2) & $\begin{array}{l}\text { Government and government enterprises } \\
\text { Manufacturing } \\
\text { Transportation and warehousing }\end{array}$ & 4.136 \\
\hline Orleans(1) & $\begin{array}{l}\text { Government and government enterprises } \\
\text { Professional and technical services } \\
\text { Health care and social assistance }\end{array}$ & 1.573 \\
\hline St. Bernard(1) & $\begin{array}{l}\text { Non-Durable Manufacturing } \\
\text { Government and government enterprises } \\
\text { Construction } \\
\text { Petroleum and coal products }{ }^{5}\end{array}$ & 1.547 \\
\hline
\end{tabular}

Note: (1) indicates central counties, (2) indicates outlying counties

\footnotetext{
${ }^{5}$ We included the fourth industry here because personal income from these four industries in total takes $20 \%$ of the total personal income in St. Bernard Parish. While in other counties (parishes) personal income from the top three industries takes around $40 \%-70 \%$ of total personal income.
} 
In Biloxi-Gulfport-Pascagoula (MA) Mississippi, the major industries in Harrison County are government and public services and retail business, which do not require large infrastructure construction to restore. Jackson County has manufacturing industries that suffered infrastructure damage in important sectors other than government and public services, so one would expect its recovery to be slower than Harrison, as we observed.

Both professional and technical services and manufacturing industries are located in the suburban county of Hancock. Comparable to Biloxi-Gulfport MA, parishes in New Orleans MA without major industries recovered sooner. Like Harrison County in Mississippi, government and public services and retail business are the major employment sectors in St. Tammany and Jefferson parishes. Yet St. Charles ranked ahead of Jefferson in resilience. This may reflect federal policies favoring construction industry for restoration, or it may be because more urban areas were damaged in Jefferson with the associated greater social and physical infrastructure that needs to be restored. Transportation and warehousing in the suburban parish, Plaquemines, may have recovered its essential functions more slowly because of their dependence on damaged public infrastructure. The professional and technical services and the petroleum and coal products manufacturing might cause Orleans and St. Bernard to be ranked the lowest of New Orleans MA.

The significant role of industrial mix on a community's recovery capability explains the negative correlation between personal income growth rate and resilience. The higher income growth rate from government and public services and retail business, compared with that from manufacturing and professional and technical services, reveals the dawning economy of the Katrina affected area in our case study. According to the report from Urban Institute (2006), this region has a high proportion of low-wage service jobs concentrated in arts, entertainment and food industries (Turner and Zedlewski 2006). The region lacks industries serving as an economic growth engine for a robust regional economy. Thus, the negative correlation between economic growth rate and the resilience indices is not truly reflecting the relation between economic capacity and community resilience. Instead, it reveals the constrained economic resources of this area. The negative correlation between the poverty rate and the resilience indices supports this interpretation. A strong economy will provide both private and public sectors valuable resources for community resilience building. To a great extent, the displaced workforce will be slower to return if there are fewer perceived future job opportunities.

The positive correlation coefficients of the total number of general-purpose government and the total general revenue per capita of county governments with 
the resilience indices indicate the potential importance of government involvement and government capacity in resilience construction. Neither the intergovernmental transferred revenue nor the general revenue from total tax significantly correlates with the resilience indices. This implies that both the financial assistance from federal and state government and the fiscal revenue supported by a prosperous economy are vital.

\section{Conclusion}

National Response Plans and Emergency Management have emphasized improving coordination within and between government jurisdictions in disaster response. Hurricane Katrina demonstrated that hierarchical models of control cannot manage critical issues such as designing, building and maintaining strong cities and that all entities in a community engage in conscious, collective efforts to reduce disaster risk over time.

The purpose of this case study is to investigate possible social and economic factors that affect the recovery capability of a community subjected to a disaster. The results reveal that the existence of segregated micro ethnic communities negatively correlates with socioeconomic resilience, and that economic capability has a positive correlation with it. The resilience index created in this project may be useful because assessment of the variation and determinants of the indicators yields important implications for U.S. homeland security policymaking. The quantitative measurement of natural disaster resilience provides guidance for vulnerable communities to learn from resilient communities to improve their plans and procedures.

The resilience index developed in this project, however, only includes the social and economic dimensions of a community in areas where data was available. Political, security, infrastructure and information dimensions should be incorporated to build a comprehensive resilience index.

In addition, the insights from this project were derived from examining only two Metropolitan Areas and nine counties (parishes) in this case study. This project would benefit from extending the research scope to all the Metropolitan Areas vulnerable to natural disasters to validate the methodology of measuring community resilience and to identify the causal linkages of the internal factors that affect resilient capabilities of communities. 


\section{Appendix 1: Variables and Data Sources}

\begin{tabular}{l|l}
\hline Variables & Data Sources \\
Racial Geography & U.S. Census Bureau 2000 \\
Economic Growth & Bureau of Economic Analysis 2001-2004 \\
$\begin{array}{l}\text { Poverty } \\
\text { General-Purpose Government } \\
\text { General Government Revenue } \\
\text { per capita }\end{array}$ & U.S. Census Bureau 2000 \\
Population Return & U.S. Census of Government 2002 \\
Employment restoration & City and County Data Book 2002 \\
Re-opened school & U.S. Census Gulf-Coast_impact_estimates 2006 January \\
Severance tax & U.S. Department of Labor and \\
& Louisiana Department of Education \\
Building Permit & Mississippi Department of Education \\
\hline & Louisianan Department of revenue \\
\hline & Mississippi State Tax Commission \\
\hline
\end{tabular}

\section{Appendix 2: Variables in Correlation Analysis}

\begin{tabular}{l|lllll}
\hline County & $\begin{array}{l}\text { Racial } \\
\text { Geography }\end{array}$ & $\begin{array}{l}\text { Economic } \\
\text { Growth }\end{array}$ & Poverty Rate & $\begin{array}{l}\text { General } \\
\text { Government }\end{array}$ & $\begin{array}{l}\text { General } \\
\text { Government } \\
\text { Revenue(per } \\
\text { capita) }\end{array}$ \\
Hancock & 0.446 & 3.004 & 14.449 & 3 & 2,749 \\
Harrison & 0.457 & 2.109 & 14.586 & 6 & 3,778 \\
Jackson & 0.57 & 2.358 & 12.748 & 5 & 3,230 \\
Jefferson & 0.653 & 3.548 & 13.653 & 7 & 3,193 \\
Orleans & 0.574 & 4.815 & 27.942 & 1 & 3,253 \\
Plaquemines & 0.476 & 3.921 & 18.029 & 1 & 4,123 \\
St. Bernard & 0.696 & 3.951 & 13.109 & 1 & 1,983 \\
St. Charles & 0.455 & 2.482 & 11.397 & 1 & 4,529 \\
St. Tammany & 0.49 & 2.710 & 9.7190 & 9 & 3,106 \\
\hline \hline
\end{tabular}




\section{Acknowledgement:}

Prepared by Oak Ridge National Laboratory, P.O. Box 2008, Oak Ridge, Tennessee 37831-6285, managed by UT-Battelle, LLC for the U. S. Department of Energy under contract no. DEAC05-00OR22725. The authors acknowledge Warren C. Jochem for his assistance in our map creation and Yi Fang for his help on the methodology. We thank Mississippi Department of Education who provided the school data. We are grateful for the excellent review from Dr. Erin Middleton and Daniel Getman (add in the submission form). Financial support for this research was made available through a research project (Capturing Hurricane Katrina Data for Analysis and Lessons-Learned Research) from the Southeast Region Research Initiative (SERRI) of the US Department of Homeland Security.

\section{Copyright}

This manuscript has been authored by employees of UT-Battelle, LLC, under contract DE-AC05-00OR22725 with the U.S. Department of Energy. Accordingly, the United States Government retains and the publisher, by accepting the article for publication, acknowledges that the United States Government retains a non-exclusive, paid-up, irrevocable, world-wide license to publish or reproduce the published form of this manuscript, or allow others to do so, for United States Government purposes. 


\section{References}

Brookings Institution, New Orleans after the Storm: Lessons from the Past and a Plan for the Future, Metropolitan Policy Program Report, 2005, Brookings Institution, Washington, DC.

Comfort , Louise K., "Cities At Risk: Hurricane Katrina and the Drowning of New Orleans,” Urban Affairs Review, 2006, Vol. 41,no.4, pp.501-516.

Comfort , Louise K., "Risk, Security and Disaster management," Annual Review of Political Science, 2005, Vol. 8, pp.335-356.

Cutter, Susan, L., Boruff, Bryan J and W. Lynn Shirley, "Social Vulnerability to Environmental Hazard,” Social Science Quarterly , 2003, vol.84, no.2, pp.242261.

Drier, Peter, "Katrina and Power in America," Urban Affairs Review, 2006, Vol.41, no.4, pp.528-549.

Salamon, Lester M. (Editor), The Tools of Government: A guide to the New Governance, 2002, Oxford University Press, Oxford, NY.

Turner, Margery Austin and Zedlewski, Sheila R. (ed.), After Katrina: Rebuilding Opportunity and Equity into the New New Orleans, 2006, The Urban Institute, Washington, DC. 